\title{
An Empirical Study on the Asymmetric Behavior of Scientometric Indicator for Journal: A Comparative Evaluation of SJR and H-Index
}

\author{
Deepjyoti Kalita ${ }^{1}$, M. Sai Baba² and Dipen Deka ${ }^{1}$ \\ 'Department of Library and Information Science, Gauhati University, Guwahati - 781014, India; \\ deepjyotilis@gauhati.ac.in, dipendeka@gauhati.ac.in \\ ${ }^{2}$ T. V. Raman Pai Chair Professor, National Institute of Advanced Studies, Indian Institute of Science Campus, \\ Bengaluru - 560012, India; msaibaba@nias.res.in
}

\begin{abstract}
Scimago Journal Rank (SJR) is a size independent measure of journal evaluation where citation coming from quality journals carries more value than citations from ordinary journals and h-index, used as a metrics for author impact when initially introduced, is now a day's used for journal evaluation in major citation databases like Scopus, Google scholar etc. Both the indicators follow different methods of calculation. SJR is a prestige based measure where the scholarly value of incoming citations matters most than its quantity, while h-index is a quantity based measure where the amount of incoming citations plus the number of published paper both matters. The current study tries to identify how the ranking value of journals changes when compared with the two indicators. The issue was addressed by taking the context of Indian journals indexed in Scopus. Even though the process of calculation for both the indicators is different, it is expected that their ultimate result is same i.e. ranking quality journals at top. The findings of ranking of quality journals represent strikingly different result given by both the indices. The dissimilarity in measure is tested using z-test for two sample means for median difference. Also the biasness of the indicators towards time and subject domains is tested on a raw count.
\end{abstract}

Keywords: H-index, Impact Metrics, Journal Evaluation, Scientometrics, SJR Indicator

\section{Introduction}

Journals are the major vehicle in science communication and evaluation of journals by single indicator metric is a major domain of research in scientometrics studies. Study of scientific communication is an age old practice (Garfield, 1995), and quantification of this process of scientific communication got major shift with the launch of Science Citation Index by Garfield (2007) in the 1960s. Later two other products came up, viz., the Social Science Citation index (Klein \& Chiang, 2004) (in the year 1973) and Arts and Humanities citation index (Garfield, 1979), currently all these are part of the Web of knowledge (www. webofknowledge.com) product of Claritive Analytics.
Basically these citation indexes have formed the very basis of bibliometrics and later given birth to two of its forms (Borgman, \& Furner, 2002) i.e. evaluative bibliometrics and relational bibliometrics. While the theories of evaluative bibliometrics is mostly based on the use of citations as a raw count and mostly influenced by the Robert Morton's Sociology of science (Merton, 1973), relational bibliometrics dealt with understanding the structure of science like subject relations, collaborations, network visualizations etc.

Garfield's introduced Journal Impact Factor (JIF) (Garfield, \& Sher, 1963) in evaluative bibliometrics as a measure of journal quality. JIF had certain limitations due to being entirely dependent on raw count of citations. Garfield 
(1979) has discussed the associated drawbacks of citation analysis for "larger and complex scientific enterprise" and argued that with proper use, it can be a cost-effective measure for science evaluation. Garfield (1979) indicated about the issue of negative citation, author homographs and value of citation for multi authorship in a discussion paper. With complex subject relationships, limitations arose for use of JIF as a single measure for journal evaluation. One such issue was giving weight-age to incoming citations to a journal, depending on the quality of journal in which the paper is being cited. To overcome this limitation, the first modification for JIF was introduced by Pinski and Narin (1976) by introducing the "Journal influence" measure which was based on complicated citation networks giving value to important nodes i.e. citations coming from high impact journals carrying value in the journal metrics. This leads to the development of Eigen factor metric (Bergstrom, 2007) (used in Journal Citation Reports) and SJR (GonzálezPereira, Guerrero-Bote, \& Moya-Anegón, 2010) (used in Scopus). Further details on such network based ranking methods can be found in the excellent review of Franceschet (2011). The JIF also didn't consider the issue of subject disparity in citations (Postma, 2007; Moed, 2005) i.e. if the number of journals published in a discipline is high, leading to the probability of citations in that discipline being high and thereby resulting in very high impact factor journals for those disciplines. This drawback of impact factor was addressed with the introduction of the indicator: 1 . Source Normalized Impact per Paper (SNIP) by Moed (2011) in 2010, and 2. modified version of SNIP introduced by Waltman, et al. (2013), for normalizing the subject discipline variance while comparing various journals across disciplines. While these size independent measures (Pinski \& Narin, 1976; Bergstrom, 2007; González-Pereira, Guerrero-Bote, \& MoyaAnegón, 2010; Moed, 2011; Waltman, Van Eck, Leeuwen van, \& Visser, 2013) have come as alternatives to dependency of JIF on citations count, Prathap, Nishy and Savithri (2016) recently have given an interesting power-weakness ratio approach for measuring journal quality where the value of incoming citations as well as the outgoing references were also given weight-age claiming (Prathap, \& Nishy, 2016) its usefulness for "localized eco system" of journals cut out from "global journal eco-system". It can be seen from the above discussion that different citation databases are using indicators having different properties, resulting in citation impact at different levels. H-index (Hirsch, 2005) even though introduced as a metrics to represent authors impact, is being used as a measure of journal impact in databases like Scopus, Google scholar etc.

In the long history of evaluative bibliometrics (Thelwell, 2008; Mingers, \& Leydesdorff, 2015; Leydesdorff, 2009) the whole process of indicator development has followed a chain where the aim was to develop an indicator which is free from the drawback of the earlier ones. By the words of Waltman and Van Eck (2012) this whole process has led to the development of some rather asymmetric matrices which aims at only lowering weakness of the older ones and thus making the scientometric process more diverting. The current study was undertaken to study the diverting results given by two widely used scientometric indicators, SJR index and h-index, for evaluating a given journal. SJR and $\mathrm{h}$-index is briefly described below.

SJR Indicator: SJR (González-Pereira, Guerrero-Bote, \& Moya-Anegón, 2010) indicator introduced in Scopus database, is a type of size independent indicator that uses the journal influence measure along with the field normalization factor. Rather it will be appropriate to say it is more complicated and modified measure of the Eigen factor centrality measure. The algorithm of the SJR indicator and about the complicated quantification of the field normalization and prestige measure are described in Golzalez-Pereira, et al. (2011). SJR uses a 3-year citation window. In SJR calculation, the citation network of a journal is first established where nodes are the journals and citations are edges, the more incoming edges to a node, more is the importance of the node. But the calculation of prestige follows an iterative process, where each node is first assigned an equal value and the iteration process is started until differences between journal prestige values in consecutive iterations do not surpass a pre-established threshold. Also, in SJR calculation the self-citation value of a journal is limited to $33 \%$. Studies (Falagas, Kouranos, Arencibia-Jorge, \& Karageorgopoulos, 2008) found many correlative behaviors of SJR algorithm with the ISI JIF.

H-index for Journals: h-index (Hirsch, 2005) is an author level indicator that tries to represent quantity and quality at the same time, with a literal representation as a scientist would have $\mathrm{h}$-index if $\mathrm{h}$ of his total publication has minimum h number of citations each. In a more simplistic way if we represent a scientist's total citations in $\mathrm{Y}$ axis and total publications in $\mathrm{X}$ axis in a $2 \mathrm{D}$ plane, then $\mathrm{h}$-index is that point in that graph, where $\mathrm{X}=\mathrm{Y}$. Since its introduction it has been a controversial indicator, but still it is used in all prominent bibliographic citation databases like Web 
of Science, Scopus and Google Scholar. The idea of using the h-index for journal evaluation along with JIF was proposed by Braun, Glänzel and Schubert (2006) for more meaningful use of the Impact Factor.

\section{Objectives of the Study}

The objective of the current study is to evaluate the disparity shown by two different journal indicators h-index and SJR index, when they are used for journal evaluation from the same source of citation network. Also, the bias of the two indicators towards journal age and their subject discipline is assessed in the study. All these were tested taking the example of Indian journals indexed in Scopus.

The following hypothesis was formulated for the study:

$H_{0}$ : SJR and h-index treat same journals equally and the ranking of a journal does not differ when it is ranked based on SJR and h-index values.

$H_{\mathrm{A}}$ : There is a no correlation among the ranking of journals when the same journal is ranked based on SJR and h-index i.e. SJR and h-index are two asymmetric indices for journal evaluation.

\section{Materials and Method Used for the Study}

Any kind of indicator whether it is an author, journal or institute is very sensitive to the database where it is applied. Scientific databases like Web of Science, Scopus or Google Scholar generally calculate these matrices based on the network established between the sources of publications that it indexes. Because of the database driven sensitivity of scientometric indicators, it is not possible to compare similar indicator from two different sources. So, to have a level playing field among the matrices to be compared in the study, the portal Scimago Journal and Country Rank (http://www.scimagojr.com/aboutus.php) was used. The portal supplies both h-index and SJR value of journals from the citation data available in Scopus database. A simple search was made in Scimago website with three controlled parameters i.e. geographical location ("India"), item type ("Journals") and Year ("2016"), that retrieved 455 journals. 2016 was chosen as a base year for data collection to have more completion in the citation data. From this master list of 455 journals, o list of top 50 journals based on SJR value was prepared and the relative ranking of those journals based on h-index value from the master list was retrieved (we shall refer to this list as SJR-h index comparative list). Another list was made for top 50 journals based on h-index value and their relative ranking based on SJR value from the master list was retrieved (we shall refer this list as $h$ index-SJR comparative list). Then the median absolute change in ranks of journals in both the list was compared (The prepared comparative rank lists are presented in Appendix 1).

Scimago also groups journals in 27 major thematic areas (macro level subjects) which are further divided into 313 specific subject categories (micro level subjects). Only the micro level subject areas of the journals were considered in the study. For determining the journal age, crucial factor was to determine the origin year. For each journal, the portal maintains a specific page called the journal metrics page which contains basic info of the journal with its performance in the last three years. For determining the origin year, the "coverage year" mentioned in the journal metrics page of Scimago portal was used. But wherever multiple coverage year information (e.g. "Indian Journal of Dermatology, Venereology and Leprology" have coverage year detail spanning three periods 1976-1982, 1985-1995, 2002-ongoing) was available, the most recent one was selected (i.e. for the current example 2002 was chosen).

\section{Results and Discussion}

\subsection{Disparity in the Journal Rank on the Basis of Selected Indexes}

As described above two comparative ranking lists of journals were prepared, in one list, the ranks of the top 50 SJR value journals were compared with their respective $h$ index based ranks in the master list of journals; and in another list, the ranks of the top $50 \mathrm{~h}$ index value journals were compared with their respective SJR index based ranks in the master list of journals. Then change in ranks of journals in both the list was compared and it was seen that both the lists have resulted in change of rankings for the top 50 journals selected in the study. In the SJR-h index comparative list, there were 7 journals in the top 50 SJR list, that suffered positive change in their ranks when they were compared with their respective $h$ index ranks, while other 43 journals ranks were downgraded in h-index based ranking list. The top ranked journal according to SJR value was Bulletin of the Astronomical Society of India, which rank became 144 in the $h$ index based ranking list. International Journal of Applied Pharmaceutics suffered highest negative change of 278 rank values as it 
was ranked 22 according to SJR, but ranked 300 according to h-index. Highest positive change of 20 rank values was observed for the journal Proceedings of the Indian Academy of Sciences, Earth and Planetary Sciences, as it was ranked 41 according to SJR value, but was ranked at 21 according to $h$ index value in the SJR-h index comparative list. The average negative change in ranks for the 43 journals whose ranks were downgraded when SJR ranks were compared with $h$ index ranks was 93.95; and the average positive change in ranks for the 8 journals whose ranks were upgraded when SJR ranks were compared with $\mathrm{h}$ index was 6.71.

Again, in the $\mathrm{h}$ index-SJR comparative list, there were 5 journals in the top $50 \mathrm{~h}$ - index journal's list that suffered positive change in their ranks, while other 45 journals ranks were downgraded in SJR based ranking list. The top ranked journal based on h index was Current Science, whose rank became 131 in the SJR based ranked list. Journal of the Indian Chemical Society suffered highest negative change of 287 rank value, as it was ranked 41 based on h index but was ranked 328 based on SJR value. Highest positive change of 39 rank values was observed for Journal of Carcinogenesis as it was ranked 42 according to $\mathrm{h}$ index but was ranked 3 based on SJR value. The average negative change in ranks for the 45 journals whose ranks were downgraded when h index ranks were compared with SJR ranks was 99.26; and the average positive change in ranks for the 5 journals whose ranks were upgraded when $\mathrm{h}$ index ranks were compared with SJR was 19.6. There are only 8 journals which are common (Appendix 1) in both the top 50 list.

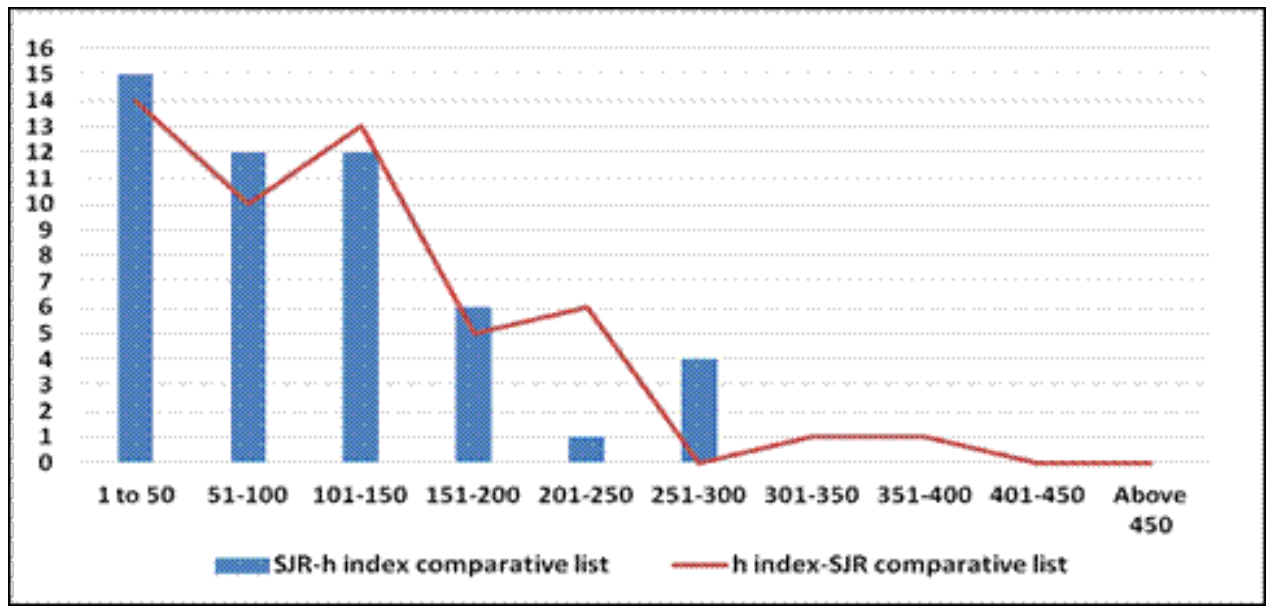

Figure 1. Frequency of journals in different range of ranks.

Because of the higher value of average negative change in rank value in both the comparative lists, further analysis of the top 50 journals from both the list was carried out, finding out the number of journals in specific range of ranks as shown in Figure 1. For the SJR-h index comparative list, the distribution of top $50 \mathrm{~h}$-index based ranked journals in the SJR based master list of 455 journals was checked and similarly for the $\mathrm{h}$ index-SJR comparative list, the top 50 SJR based ranked journals distribution was checked in $\mathrm{h}$ index based the master list.

Figure 1, it can be observed that SJR based ranking was able to place a journal in top 50 , which was placed in the range of 251 to 300 according to $h$-index based ranking in the master list. $\mathrm{H}$-index based rank placed a journal in top 50, which was ranked in the range 351-400 in master list based on SJR value.

Both SJR and h-index attempt to reflect the quality of journals based on their value, greater the value, greater being the quality. But the higher value of average change in rankings in both the list and scatter of journals at all the different rank ranges (Figure 1), reflects the difference in the way journals were ranked by both the indicators. Further analysis is needed to understand the underlying association between the rankings produced by both the indicator. A monotonic relationship among the rankings of journals is expected no matter what scientometric indicator is used to rank them, as all journal evaluation measures only tries to rank the best journals on top. As the same group of 50 journals was evaluated by two different measures, i.e. the population is same but measures of data collection were different $z$-test for two samples mean was chosen suitable for evaluating the mean in differences produced in the two groups. More on the use of $\mathrm{z}$-test can be found in Kothari (2004). The two tailed z-test results for both the SJR-h index comparative ranking list and $h$ index-SJR comparative ranking list is presented in Table 1. 
Table 1. z-Test: Two sample for means

\begin{tabular}{|l|c|c|l|c|c|}
\hline \multicolumn{2}{|c|}{ SJR-h index comparative list } & \multicolumn{3}{c|}{ h index-SJR comparative list } \\
\hline & Variable 1 & Variable 2 & & Variable 1 & Variable 2 \\
\hline Mean & 25.5 & 104.22 & Mean & 25.5 & 112.5 \\
\hline Known Variance & 212.5 & 6054.74 & Known Variance & 212.5 & 7205.071 \\
\hline Observations & 50 & 50 & Observations & 50 & 50 \\
\hline $\begin{array}{l}\text { Hypothesized } \\
\text { Mean Difference }\end{array}$ & 0 & & $\begin{array}{l}\text { Hypothesized } \\
\text { Mean Difference }\end{array}$ & 0 & \\
\hline $\mathrm{z}$ & -7.03124 & & $\mathrm{z}$ & -7.14288 & \\
\hline $\mathrm{P}(\mathrm{Z}<=\mathrm{z})$ one-tail & $1.02351 \mathrm{E}-12$ & & $\mathrm{P}(\mathrm{Z}<=\mathrm{z})$ one-tail & $4.57 \mathrm{E}-13$ & \\
\hline $\mathrm{z}$ Critical one-tail & 1.644853627 & & $\mathrm{z}$ Critical one-tail & 1.644854 & \\
\hline $\mathrm{P}(\mathrm{Z}<=\mathrm{z})$ two-tail & $2.04703 \mathrm{E}-12$ & & $\mathrm{P}(\mathrm{Z}<=\mathrm{z})$ two-tail & $9.14 \mathrm{E}-13$ & \\
\hline $\mathrm{z}$ Critical two-tail & 1.959963985 & & $\mathrm{z}$ Critical two-tail & 1.959964 & \\
\hline
\end{tabular}

The calculated $\mathrm{z}$ value for one tailed and two tailed distributions with a hypothesized mean difference of 0 at a $5 \%$ level of significance for both the SJR-h index comparative list and $\mathrm{h}$ index-SJR comparative list was found below than the critical value. Therefore, the null hypothesis $\left(\mathrm{H}_{0}\right)$ was rejected and the alternate hypothesis $\left(\mathrm{H}_{\mathrm{A}}\right)$ was accepted. SJR and h-index don't treat same journals equally and the ranking of a journal differs when it is ranked based on SJR and h-index values, proving the asymmetric behavior of SJR and $h$-index for journals.

\subsection{Analysis of Disparity in Treating Journals of Different Subjects by $\mathrm{H}$-Index and SJR Indicator}

Analysis of the subjects of the top journals from both the groups was carried out to check the presence of disparity in both the matrices in treating journals of different subjects. In this analysis subject domains associated with each journal were collected from the taxonomy of the subjects associated with each the journal, from the Scimago Journal rank website. In this process if a journal is found to be associated with multiple subject categories, then each subject category was given a count for the journal. In the top 50 journal based on h-index, journals from 59 subject categories featured, while same in the SJR rank list was 61 (Appendix 2). It is seen that in both the lists, journals from medicine, pharmacy and biological sciences featured most, reflecting the enhanced research in these domains. The micro level analysis of subjects on the collected top 50 list of journals, no conclusive disparity in treatment of journals from different subject disciplines was found.

\subsection{Comparison in the Treatment of Journals of Different Age}

A good scientometric indicator for journal should be able to treat journals based only on quality independent of their age. It is possible that a journal may be new, but it has published quality contents, for which the journal should get its due valuation.

During the age evaluation, 2016 was taken as current year as data was collected for the same in the study and the beginning year was chosen as the coverage year mentioned in the data source (Appendix 1 for more details). Findings showed that the average age of the journals which featured in h-index list was 29.32 years, while the same for the journals in SJR list was 13.66 year. This implies that SJR indicator was able to place young journals in the top 50 position as compared to h-index indicator and reflecting the biasness of h-index towards older journals.

\section{Summary}

SJR and h-index both follows two entirely different methods for ranking, while h-index is entirely dependent on citations; SJR employs a different method of giving weight-age to incoming citations. As both the indicators are used for the evaluation of journal, it is important to know how the evaluation differs between SJR and h-index. 
Based on the current study conducted by taking 50 selected top Indian journals, variation in the assessment of journal by the selected two indicators could be seen. The relative average change in rankings was found quite high (93.95 ranking positions for SJR-h index comparative list and 99.26 for h index-SJR comparative list). The higher value of this average change in rankings has led to conduct a frequency count in selective range of ranking. The SJR based list featured journals in the top 50, which was ranked in the range of 251-300 according to h-index value in the master list and the h-index based top 50 list featured journals lying in the range of 351-400 in SJR ranking. From the findings of the $z$-test for two sample mean, the observed $z$ value was found below the critical value that negates any kind of association in the compared ranking list. Micro level subject study didn't yield any conclusive evidence to reflect any kind of subject disparity by the two indicators in the top 50 list. The journal age study yields feature of young journals (average age of journal 13.66 years) in the top 50 list by SJR indicator, which was very high (average age 29.32 years) for top $50 \mathrm{~h}$-index list. This proves the biasness of h-index towards old journals compared to young journals.

Journal evaluation and journal quality both are multifaceted notions (Roussea, 2002). The aim of the study is not to reflect on the quality of the journal but to analyze the differences that arise in measuring the quality due to use of any given indicator. It is hoped that better quality indicators for journal impact would emerge.

\section{References}

Borgman, C.L. \& Furner, J. (2002). Scholarly communication and bibliometrics, Annual Review of Information Science and Technology. 36:3-72. https:// doi.org/10.1002/aris.1440360102.

Bergstrom, M. (2007). Measuring the value and prestige of scholarly journals. College \& Research Libraries News. 68:3146. https://doi.org/10.5860/crln.68.5.7804.

Braun T, Glänzel W \& Schubert A. (2006). A Hirsch-type index for journals. Scientometrics. 69: 169-173. https:// doi.org/10.1007/s11192-006-0147-4.

Falagas, M.E., Kouranos, V.D., Arencibia-Jorge, R. \& Karageorgopoulos, Drosos E.(2008). Comparison of SCImago journal rank indicator with journal impact factor. The FASEB Journal. 22: 2623-2628. https://doi. org/10.1096/fj.08-107938. PMid: 18408168.
Franceschet, M. (2011). PageRank: standing on the shoulders of giants. ACM Communications. 54:92-101. https://doi. org/10.1145/1953122.1953146.

Garfield, E. (1955). Citation Indexes for Science: A new dimension in documentation through association of ideas. Science, 122:108-111. https://doi.org/10.1126/ science.122.3159.108. PMid: 14385826.

Garfield, E. (2007). The evolution of the science citation index. International Microbiology. 10:65-69. PMid: 17407063.

Garfield, E. (1979). Will ISI's arts and humanities citation index revolutionize scholarship? Current Contents. 35:5-9.

Garfield, E \& Sher, I.H. (1963). New factors in the evaluation of scientific literature through citation indexing. American Documentation. 14:195-201. https://doi. org/10.1002/asi.5090140304.

Garfield, E. (1979). Is citation analysis legitimate evaluation tool? Scientometric. 1: 359-375. https://doi. org/10.1007/BF02019306.

González-Pereira, B., Guerrero-Bote V.P. \& MoyaAnegón F. (2010). A new approach to the metric of journals' scientific prestige: The SJR indicator. Journal of Informetrics. 4: 379-391. https://doi.org/10.1016/j. joi.2010.03.002.

Hirsch, J. (2005). An index to quantify an individual's scientific research output. Proceedings of the National Academy of Sciences of the United States of America. 102: 16569-16572. https://doi.org/10.1073/pnas.0507655102. PMid: 16275915, PMCid :PMC1283832.

Klein, Daniel B. \& Chiang, Eric. (2004). The Social Science Citation Index: A Black Box with an Ideological Bias? Econ Journal Watch. 1:134-165.

Kothari, C.R. (2004). Research methodology: methods and techniques. 2nd revised ed. New Delhi: New age international publishers.

Leydesdorff, L. (2009). How are new citation-based journal indicators adding to the bibliometric toolbox? Journal of American Society for Information Science \& Technology. 60:1327-1336. https://doi.org/10.1002/ asi.21024.

Merton, R.K. (1973). The Sociology of Science: Theoretical and Empirical Investigations. 1st ed. Chicago: University of Chicago Press.

Moed, H. F. (2005). Citation Analysis in Research Evaluation. 1st ed. Dordrecht: Kluwer Academic Publishers. 
Moed, H. (2011). The Source-Normalized Impact per Paper (SNIP) is a valid and sophisticated indicator of journal citation impact. Journal of Association of Information Science and Technology. 62:211-213. https://doi.org/10.1002/asi.21424.

Mingers, John \& Leydesdorff, L. (2015). A review of theory and practice in scientometrics. European Journal of Operational Research. 246:1-19. https://doi. org/10.1016/j.ejor.2015.04.002.

Pinski, G. \& Narin, F.(1976). Citation influence for journal aggregates of scientific publcations: Theory with application to the literature of physics. Information Processing \& Management. 12:297-312. https://doi. org/10.1016/0306-4573(76)90048-0.

Postma, E. (2007). Inflated impact factors? The true impact of evolutionary papers in non-evolutionary journals. PLoS One. 2: 999. https://doi.org/10.1371/journal. pone.0000999. PMid: 17912376, PMCid: PMC1994586.

Prathap G, Nishy P \& Savithri, S. (2016). On the orthogonality of indicators of journal performance. Current
Science. 111:876-881. https://doi.org/10.18520/cs/ v111/i5/876-881.

Prathap, G. \& Nishy, P. (2016). An alternative size-independent journal performance indicator for science on the periphery. Current Science. 111: 1802-1810. https://doi. org/10.18520/cs/v111/i11/1802-1810.

Roussea, Ronald. (2002). Journal Evaluation: Technical and practical issues. Library Trends. 50: 418-439.

Thelwell, Mike. (2008). Bibliometrics to webometrics. Journal of Information Science. 34: 605-621. https:// doi.org/10.1177/0165551507087238.

Waltman L, Van Eck N.J., Leeuwen van T.M. \& Visser, M.S. (2013). Some modifications to the SNIP journal impact indicator. Journal of Informatrics, 7: 272-285. https:// doi.org/10.1016/j.joi.2012.11.011.

Waltman, L. \& Van Eck, N.J. (2012). The inconsistency of the h-index. Journal of the American Society for Information Science and Technology. 63: 406-415. https://doi. org/10.1002/asi.21678.

\section{Appendix 1}

\begin{tabular}{|c|c|c|c|c|c|c|c|c|c|c|c|}
\hline \multicolumn{6}{|c|}{ SJR-h index comparative list } & \multicolumn{6}{|c|}{$h$ index-SJR comparative list } \\
\hline Top SJR & $\begin{array}{c}\text { SJR } \\
\text { Rank }\end{array}$ & $\begin{array}{c}\mathrm{H} \text { index } \\
\text { ranks }\end{array}$ & $\begin{array}{c}\text { Begin } \\
\text { year }\end{array}$ & $\begin{array}{l}\text { Cur- } \\
\text { rent }\end{array}$ & Age & Top H Index & $\begin{array}{c}H \text { index } \\
\text { ranks }\end{array}$ & $\begin{array}{c}\text { SJR } \\
\text { ranks }\end{array}$ & $\begin{array}{c}\text { Begin } \\
\text { year }\end{array}$ & $\begin{array}{l}\text { Cur- } \\
\text { rent }\end{array}$ & Age \\
\hline $\begin{array}{l}\text { Bulletin of the } \\
\text { Astronomical Society } \\
\text { of India }\end{array}$ & 1 & 144 & 2008 & 2016 & 8 & Cur-rent Scn. & 1 & 131 & 1993 & 2016 & 23 \\
\hline $\begin{array}{l}\text { Pharma-cognosy } \\
\text { Reviews }\end{array}$ & 2 & 58 & 2009 & 2016 & 7 & $\begin{array}{l}\text { Indian Jl. of Medi-cal } \\
\text { Re-search }\end{array}$ & 2 & 4 & 1950 & 2016 & 66 \\
\hline Jl. of Carcino-genesis & 3 & 42 & 2002 & 2016 & 14 & $\begin{array}{l}\text { Indian Jl. of Experi- } \\
\text { mental Bio-logy }\end{array}$ & 3 & 8 & 1965 & 2016 & 51 \\
\hline $\begin{array}{l}\text { Indian Jl. of Medi-cal } \\
\text { Re-search }\end{array}$ & 4 & 2 & 1950 & 2016 & 66 & Jl. of Bio-scns. & 4 & 11 & 1979 & 2016 & 37 \\
\hline Noise and Health & 5 & 22 & 2002 & 2016 & 14 & $\begin{array}{l}\text { Bulle-tin of Mate-rials } \\
\text { Scn. }\end{array}$ & 5 & 119 & 1979 & 2016 & 37 \\
\hline $\begin{array}{l}\text { Jl. of Pharma-cology } \\
\text { and Pharma-cothera- } \\
\text { peutics }\end{array}$ & 6 & 125 & 2010 & 2016 & 6 & $\begin{array}{l}\text { The Jl. of the Asso- } \\
\text { ciation of Phy-sicians } \\
\text { of India }\end{array}$ & 6 & 210 & 1961 & 2016 & 55 \\
\hline
\end{tabular}




\begin{tabular}{|c|c|c|c|c|c|c|c|c|c|c|c|}
\hline $\begin{array}{l}\text { Inter-national Jl. of } \\
\text { Artificial Intelli-gence }\end{array}$ & 7 & 142 & 2009 & 2016 & 7 & $\begin{array}{l}\text { Indian Jl. of Pharma- } \\
\text { cology }\end{array}$ & 7 & 51 & 1994 & 2016 & 22 \\
\hline $\begin{array}{l}\text { Indian Jl. of Experi- } \\
\text { mental Biology }\end{array}$ & 8 & 3 & 1965 & 2016 & 51 & $\begin{array}{l}\text { Jl. of Post-gradu-ate } \\
\text { Medi-cine }\end{array}$ & 8 & 68 & 1961 & 2016 & 55 \\
\hline $\begin{array}{l}\text { Conser-vation and } \\
\text { Society }\end{array}$ & 9 & 124 & 2011 & 2016 & 5 & $\begin{array}{l}\text { Indian Jl. of Pharma- } \\
\text { ceuti-cal Scns. }\end{array}$ & 9 & 97 & 1978 & 2016 & 38 \\
\hline $\begin{array}{l}\text { North American Jl. of } \\
\text { Medical Sciences }\end{array}$ & 10 & 103 & 2011 & 2016 & 5 & Jl. of Chemi-cal Scns. & 10 & 99 & 2002 & 2016 & 14 \\
\hline Jl. of Bio-sciences & 11 & 4 & 1979 & 2016 & 37 & Indian Pedi-atrics & 11 & 76 & 1964 & 2016 & 52 \\
\hline $\begin{array}{l}\text { Jl. of Conser-vative } \\
\text { Dentistry }\end{array}$ & 12 & 146 & 2011 & 2016 & 5 & $\begin{array}{l}\text { Indian Jl. of } \\
\text { Phy-siology and } \\
\text { Pharmacology }\end{array}$ & 12 & 149 & 1959 & 2016 & 57 \\
\hline Tropical Ecology & 13 & 70 & 1998 & 2016 & 18 & $\begin{array}{l}\text { Indian Jl. of Pedi- } \\
\text { atrics }\end{array}$ & 13 & 113 & 1950 & 2016 & 66 \\
\hline $\begin{array}{l}\text { Annals of Thoracic } \\
\text { Medicine }\end{array}$ & 14 & 64 & 2006 & 2016 & 10 & $\begin{array}{l}\text { Jl. of Scienti-fic and } \\
\text { Indus-trial Re-search }\end{array}$ & 14 & 196 & 1994 & 2016 & 22 \\
\hline $\begin{array}{l}\text { Indian Jl. of Medical } \\
\text { Micro-biology }\end{array}$ & 15 & 17 & 2003 & 2016 & 13 & $\begin{array}{l}\text { Indian Jl. of Oph-thal- } \\
\text { mology }\end{array}$ & 15 & 21 & 1971 & 2016 & 45 \\
\hline $\begin{array}{l}\text { Indian Jl. of Derma- } \\
\text { tology, Venereo-logy and } \\
\text { Lepro-logy }\end{array}$ & 16 & 30 & 2002 & 2016 & 14 & Neuro-logy India & 16 & 69 & 1994 & 2016 & 22 \\
\hline $\begin{array}{l}\text { Jl. of Anaes-thesio-logy } \\
\text { Clinical Pharma-cology }\end{array}$ & 17 & 96 & 2002 & 2016 & 14 & $\begin{array}{l}\text { Indian Jl. of Medi-cal } \\
\text { Micro-biology }\end{array}$ & 17 & 15 & 2003 & 2016 & 13 \\
\hline $\begin{array}{l}\text { Jl. of Global Infec-tious } \\
\text { Diseases }\end{array}$ & 18 & 133 & 2011 & 2016 & 5 & $\begin{array}{l}\text { Indian Jl. of Chemi- } \\
\text { stry - Section B Orga- } \\
\text { nic and Medi-cinal } \\
\text { Chemi-stry }\end{array}$ & 18 & 243 & 1996 & 2016 & 20 \\
\hline $\begin{array}{l}\text { Physio-logy and } \\
\text { Molecu-lar Bio-logy of } \\
\text { Plants }\end{array}$ & 19 & 75 & 2000 & 2016 & 16 & $\begin{array}{l}\text { Pra-mana - Jl. of } \\
\text { Physics }\end{array}$ & 19 & 157 & 1973 & 2016 & 43 \\
\hline $\begin{array}{l}\text { Hepa-tology Inter- } \\
\text { national }\end{array}$ & 20 & 32 & 2008 & 2016 & 8 & $\begin{array}{l}\text { Jl. of Food Scen. and } \\
\text { Tech-nology }\end{array}$ & 20 & 24 & 1994 & 2016 & 22 \\
\hline $\begin{array}{l}\text { Indian Jl. of Ophthal- } \\
\text { mology }\end{array}$ & 21 & 15 & 1971 & 2016 & 45 & $\begin{array}{l}\text { Procee-dings of the } \\
\text { Indian Aca-demy } \\
\text { of Scins., Earth and } \\
\text { Plane-tary Scins. }\end{array}$ & 21 & 41 & 1978 & 2016 & 38 \\
\hline
\end{tabular}




\begin{tabular}{|c|c|c|c|c|c|c|c|c|c|c|c|}
\hline $\begin{array}{l}\text { Inter-national Jl. of } \\
\text { Applied Pharma-ceutics }\end{array}$ & 22 & 300 & 2011 & 2016 & 5 & Noise and Health & 22 & 5 & 2002 & 2016 & 14 \\
\hline $\begin{array}{l}\text { Journal of Vector Borne } \\
\text { Diseases }\end{array}$ & 23 & 40 & 2003 & 2016 & 13 & $\begin{array}{l}\text { Sa-dhana - Aca-demy } \\
\text { Procee-dings in Engi- } \\
\text { neering Sciens. }\end{array}$ & 23 & 204 & 1984 & 2016 & 32 \\
\hline $\begin{array}{l}\text { Jl. of Food Science and } \\
\text { Techno-logy }\end{array}$ & 24 & 20 & 1994 & 2016 & 22 & $\begin{array}{l}\text { Natio-nal Medi-cal Jl. } \\
\text { of India }\end{array}$ & 24 & 233 & 1988 & 2016 & 28 \\
\hline $\begin{array}{l}\text { Jl. of Human Repro- } \\
\text { ductive Sciences }\end{array}$ & 25 & 120 & 2009 & 2016 & 7 & $\begin{array}{l}\text { Jl. of Envi-ron-mental } \\
\text { Bio-logy }\end{array}$ & 25 & 75 & 1988 & 2016 & 28 \\
\hline $\begin{array}{l}\text { Middle East African Jl. } \\
\text { of Ophthal-mology }\end{array}$ & 26 & 159 & 2011 & 2016 & 5 & $\begin{array}{l}\text { Jl of the Geo-logical } \\
\text { Society of India }\end{array}$ & 26 & 124 & 1979 & 2016 & 37 \\
\hline $\begin{array}{l}\text { Indian Journal of } \\
\text { Clinical Biochemistry }\end{array}$ & 27 & 43 & 1986 & 2016 & 30 & $\begin{array}{l}\text { Intern-ational Jl. } \\
\text { of Pharm-Tech Re- } \\
\text { search }\end{array}$ & 27 & 57 & 2009 & 2016 & 7 \\
\hline $\begin{array}{l}\text { Surgical Neuro-logy } \\
\text { Inter-national }\end{array}$ & 28 & 112 & 2011 & 2016 & 5 & $\begin{array}{l}\text { Indian Jl. of Medi-cal } \\
\text { Sciens. }\end{array}$ & 28 & 156 & 2013 & 2016 & 3 \\
\hline Indian Jl. of Psy-chiatry & 29 & 85 & 2009 & 2016 & 7 & $\begin{array}{l}\text { Indian Jl. of Che- } \\
\text { mistry - Section A } \\
\text { Inor-ganic, Phy-sical, } \\
\text { Theore-tical and } \\
\text { Analy-tical Che-mistry }\end{array}$ & 29 & 215 & 1996 & 2016 & 20 \\
\hline $\begin{array}{l}\text { Global Jl. of Flexi-ble } \\
\text { Sys-tems Man-agement }\end{array}$ & 30 & 170 & 2006 & 2016 & 10 & $\begin{array}{l}\text { Indian Jl. of Derma- } \\
\text { tology, Vene-reology } \\
\text { and Lepro-logy }\end{array}$ & 30 & 16 & 2002 & 2016 & 14 \\
\hline $\begin{array}{l}\text { Saudi Journal of Gas- } \\
\text { tro-entero-logy }\end{array}$ & 31 & 73 & 2006 & 2016 & 10 & $\begin{array}{l}\text { Indian Jl. of Gastro- } \\
\text { entero-logy }\end{array}$ & 31 & 96 & 1982 & 2016 & 34 \\
\hline $\begin{array}{l}\text { JP Jl. of Heat and Mass } \\
\text { Transfer }\end{array}$ & 32 & 296 & 2010 & 2016 & 6 & $\begin{array}{l}\text { Hepato-logy Intern- } \\
\text { ational }\end{array}$ & 32 & 20 & 2008 & 2016 & 8 \\
\hline $\begin{array}{l}\text { Jl. of Ad-vanced Pharma- } \\
\text { ceutical Techno-logy and } \\
\text { Research }\end{array}$ & 33 & 104 & 2010 & 2016 & 6 & $\begin{array}{l}\text { Econo-mic \& Politi- } \\
\text { cal Week-ly }\end{array}$ & 33 & 122 & 2007 & 2016 & 9 \\
\hline $\begin{array}{l}\text { Interna-tional Jl. of } \\
\text { Tricho-logy }\end{array}$ & 34 & 193 & 2009 & 2016 & 7 & $\begin{array}{l}\text { Indian Jl. of Bioche- } \\
\text { mistry and Biophy-sics }\end{array}$ & 34 & 127 & 1972 & 2016 & 44 \\
\hline $\begin{array}{l}\text { Jl. of Natural Science, } \\
\text { Biology and Medicine }\end{array}$ & 35 & 126 & 2010 & 2016 & 6 & Indian Heart Journal & 35 & 137 & 1964 & 2016 & 52 \\
\hline $\begin{array}{l}\text { Endo-scopic Ultra- } \\
\text { sound }\end{array}$ & 36 & 195 & 2012 & 2016 & 4 & $\begin{array}{l}\text { Indian Jl. of Pure and } \\
\text { App-lied Physics }\end{array}$ & 36 & 141 & 1993 & 2016 & 23 \\
\hline
\end{tabular}




\begin{tabular}{|c|c|c|c|c|c|c|c|c|c|c|c|}
\hline $\begin{array}{l}\text { Jl. of Indian Acade-my } \\
\text { of Forensic Medicine }\end{array}$ & 37 & 276 & 2011 & 2016 & 5 & $\begin{array}{l}\text { Indian Jl. of Pure } \\
\text { and App-lied } \\
\text { Mathematics }\end{array}$ & 37 & 214 & 1996 & 2016 & 20 \\
\hline $\begin{array}{l}\text { Indian Jl. of Derma- } \\
\text { tology }\end{array}$ & 38 & 87 & 2006 & 2016 & 10 & Jl. of Gene-tics & 38 & 93 & 1985 & 2016 & 31 \\
\hline Cyto-Jl. & 39 & 82 & 2004 & 2016 & 12 & Indian Drugs & 39 & 382 & 1989 & 2016 & 27 \\
\hline $\begin{array}{l}\text { Jl. of Minimal Access } \\
\text { Surgery }\end{array}$ & 40 & 99 & 2005 & 2016 & 11 & $\begin{array}{l}\text { Jl. of Vector Borne } \\
\text { Disea-ses }\end{array}$ & 40 & 23 & 2003 & 2016 & 13 \\
\hline $\begin{array}{l}\text { Proceed-ings of the } \\
\text { Indian Academy of } \\
\text { Sciences, Earth and } \\
\text { Planetary Sciences }\end{array}$ & 41 & 21 & 1978 & 2016 & 38 & $\begin{array}{l}\text { Jl. of the Indian Che- } \\
\text { mical Society }\end{array}$ & 41 & 328 & 1996 & 2016 & 20 \\
\hline $\begin{array}{l}\text { Jl. of Plant Bioche-mistry } \\
\text { and Biotech-nology }\end{array}$ & 42 & 69 & 1992 & 2016 & 24 & Jl. of Carci-noge-nesis & 42 & 3 & 2002 & 2016 & 14 \\
\hline $\begin{array}{l}\text { Pharma-cognosy } \\
\text { Magazine }\end{array}$ & 43 & 68 & 2008 & 2016 & 8 & $\begin{array}{l}\text { Indian Jl. of Clini-cal } \\
\text { Bioche-mistry }\end{array}$ & 43 & 27 & 1986 & 2016 & 30 \\
\hline $\begin{array}{l}\text { Jl. of Nanome-dicine } \\
\text { and Nanotech-nology }\end{array}$ & 44 & 179 & 2010 & 2016 & 6 & $\begin{array}{l}\text { Intern-ational Jl. of } \\
\text { Phar-macy and Phar- } \\
\text { maceu-tical Sciens. }\end{array}$ & 44 & 142 & 2009 & 2016 & 7 \\
\hline Indian Jl. of Urology & 45 & 81 & 2006 & 2016 & 10 & $\begin{array}{l}\text { Interna-tional Jl. of } \\
\text { Chem.-Tech Re-search }\end{array}$ & 45 & 145 & 2009 & 2016 & 7 \\
\hline $\begin{array}{l}\text { Jl. of Stem Cells and } \\
\text { Regene-rative Medicine }\end{array}$ & 46 & 226 & 2010 & 2016 & 6 & $\begin{array}{l}\text { Indian Jl. of Fibre and } \\
\text { Textile Re-search }\end{array}$ & 46 & 139 & 1990 & 2016 & 26 \\
\hline $\begin{array}{l}\text { Annals of Neuro- } \\
\text { sciences }\end{array}$ & 47 & 275 & 2011 & 2016 & 5 & $\begin{array}{l}\text { Indian Jl. of Micro- } \\
\text { biology }\end{array}$ & 47 & 50 & 1996 & 2016 & 20 \\
\hline $\begin{array}{l}\text { Sankhya: The Indian Jl. } \\
\text { of Statistics }\end{array}$ & 48 & 153 & 2005 & 2016 & 11 & $\begin{array}{l}\text { Indian Jl. of Chemi- } \\
\text { cal Techno-logy }\end{array}$ & 48 & 182 & 1994 & 2016 & 22 \\
\hline $\begin{array}{l}\text { Indian Jl. of Anaes- } \\
\text { thesia }\end{array}$ & 49 & 122 & 2010 & 2016 & 6 & $\begin{array}{l}\text { Indian Jl. of Dental } \\
\text { Re-search }\end{array}$ & 49 & 165 & 1989 & 2016 & 27 \\
\hline $\begin{array}{l}\text { Indian Jl. of Micro- } \\
\text { biology }\end{array}$ & 50 & 47 & 1996 & 2016 & 20 & Indian Jl. of Cancer & 50 & 102 & 1965 & 2016 & 51 \\
\hline & & & \multicolumn{2}{|c|}{ Total age } & 683 & & & \multicolumn{2}{|c|}{ Total age } & \multicolumn{2}{|c|}{1466} \\
\hline & & & \multicolumn{3}{|c|}{ Average age 13.66} & & & \multicolumn{2}{|c|}{ Average age } & \multicolumn{2}{|c|}{29.32} \\
\hline
\end{tabular}




\section{Appendix 2}

\begin{tabular}{|c|c|c|c|c|c|c|c|c|c|c|c|}
\hline \multicolumn{6}{|c|}{ Micro level subject categories of top $50 \mathrm{~h}$ index journals } & \multicolumn{6}{|c|}{ Micro level subject categories of top 50 SJR journals } \\
\hline S.N. & Subject category & Ns. & S.N. & Subject category & Ns. & S.N. & Subject category & Ns. & S.N. & Subject category & Ns. \\
\hline 1 & $\begin{array}{l}\text { Medicine } \\
\text { (miscellaneous) }\end{array}$ & 5 & 31 & Hepato-logy & 1 & 1 & Pharma-cology & 5 & 31 & Food Science & 1 \\
\hline 2 & Pharma-cology & 5 & 32 & $\begin{array}{l}\text { Econo-mics, } \\
\text { Econo-metrics } \\
\text { and Finance } \\
\text { (miscel-laneous) }\end{array}$ & 1 & 2 & $\begin{array}{l}\text { Medicine (miscel- } \\
\text { laneous) }\end{array}$ & 4 & 32 & $\begin{array}{l}\text { Repro-ductive } \\
\text { Medicine }\end{array}$ & 1 \\
\hline 3 & $\begin{array}{l}\text { Pharmaceu-tical } \\
\text { Science }\end{array}$ & 4 & 33 & Biophy-sics & 1 & 3 & Plant Science & 4 & 33 & $\begin{array}{l}\text { Clinical Bioche- } \\
\text { mistry }\end{array}$ & 1 \\
\hline 4 & $\begin{array}{l}\text { Multidisci- } \\
\text { plinary }\end{array}$ & 3 & 34 & $\begin{array}{l}\text { Cardio-logy and } \\
\text { Cardio-vascular } \\
\text { Medicine }\end{array}$ & 1 & 4 & $\begin{array}{l}\text { Pharma-ceutical } \\
\text { Science }\end{array}$ & 4 & 34 & $\begin{array}{l}\text { Psychia-try and } \\
\text { Mental Health }\end{array}$ & 1 \\
\hline 5 & $\begin{array}{l}\text { Chemistry } \\
\text { (miscel-laneous) }\end{array}$ & 3 & 35 & $\begin{array}{l}\text { Applied Mathe- } \\
\text { matics }\end{array}$ & 1 & 5 & Surgery & 4 & 35 & $\begin{array}{l}\text { Business and } \\
\text { Inter-national } \\
\text { Manage-ment }\end{array}$ & 1 \\
\hline 6 & $\begin{array}{l}\text { Chemical } \\
\text { Engineering } \\
\text { (miscel-laneous) }\end{array}$ & 3 & 36 & Genetics & 1 & 6 & Biotech-nology & 3 & 36 & $\begin{array}{l}\text { Atomic and } \\
\text { Molecular } \\
\text { Physics, and } \\
\text { Optics }\end{array}$ & 1 \\
\hline 7 & Pharma-cology & 3 & 37 & $\begin{array}{l}\text { Clinical Bioche- } \\
\text { mistry }\end{array}$ & 1 & 7 & Dermato-logy & 3 & 37 & $\begin{array}{l}\text { Earth and } \\
\text { Planetary } \\
\text { Sciences (miscel- } \\
\text { laneous) }\end{array}$ & 1 \\
\hline 8 & $\begin{array}{l}\text { Materials Science } \\
\text { (miscel-laneous) }\end{array}$ & 2 & 38 & $\begin{array}{l}\text { Dentistry (miscel- } \\
\text { laneous) }\end{array}$ & 1 & 8 & Infectious Diseases & 3 & 38 & $\begin{array}{l}\text { Agro-nomy and } \\
\text { Crop Science }\end{array}$ & 1 \\
\hline 9 & $\begin{array}{l}\text { Pediatrics, } \\
\text { Perinato-logy and } \\
\text { Child Health }\end{array}$ & 2 & 39 & Cell Biology & 1 & 9 & Surgery & 3 & 39 & $\begin{array}{l}\text { Biome-dical } \\
\text { Engineer-ing }\end{array}$ & 1 \\
\hline 10 & $\begin{array}{l}\text { Physics and } \\
\text { Astronomy } \\
\text { (miscel-laneous) }\end{array}$ & 2 & 40 & $\begin{array}{l}\text { Mecha-nics of } \\
\text { Materials }\end{array}$ & 1 & 10 & $\begin{array}{l}\text { Bioche-mistry, } \\
\text { Genetics and } \\
\text { Molecular Biology } \\
\text { (miscel-laneous) }\end{array}$ & 3 & 40 & Urology & 1 \\
\hline 11 & $\begin{array}{l}\text { Inorganic } \\
\text { Chemistry }\end{array}$ & 2 & 41 & $\begin{array}{l}\text { Pharma-cology } \\
\text { (medical) }\end{array}$ & 1 & 11 & Plant Science & 3 & 41 & Bioche-mistry & 1 \\
\hline 12 & Drug Discovery & 2 & 42 & Physio-logy & 1 & 12 & Molecular Biology & 3 & 42 & $\begin{array}{l}\text { Neuro-science } \\
\text { (miscel-laneous) }\end{array}$ & 1 \\
\hline
\end{tabular}




\begin{tabular}{|c|c|c|c|c|c|c|c|c|c|c|c|}
\hline 13 & $\begin{array}{l}\text { Health, } \\
\text { Toxicology and } \\
\text { Mutagenesis }\end{array}$ & 2 & 43 & $\begin{array}{l}\text { Infectious } \\
\text { Diseases }\end{array}$ & 1 & 13 & Ecology & 2 & 43 & $\begin{array}{l}\text { Statistics and } \\
\text { Pro-bability }\end{array}$ & 1 \\
\hline 14 & Oncology & 2 & 44 & $\begin{array}{l}\text { Political Science } \\
\text { and Inter-national } \\
\text { Relations }\end{array}$ & 1 & 14 & Hepato-logy & 2 & 44 & Micro-biology & 1 \\
\hline 15 & $\begin{array}{l}\text { Bioche-mistry, } \\
\text { Genetics and } \\
\text { Molecular Biology } \\
\text { (miscel-laneous) }\end{array}$ & 2 & 45 & Bio-chemistry & 1 & 15 & Ophthal-mology & 2 & 45 & Cancer Research & 1 \\
\hline 16 & $\begin{array}{l}\text { Physical and } \\
\text { Theoretical } \\
\text { Chemistry }\end{array}$ & 2 & 46 & $\begin{array}{l}\text { Mathe-matics } \\
\text { (miscel-laneous) }\end{array}$ & 1 & 16 & Gastroen-terology & 2 & 46 & $\begin{array}{l}\text { Public Health, } \\
\text { Environ-mental } \\
\text { and Occu- } \\
\text { pational Health }\end{array}$ & 1 \\
\hline 17 & $\begin{array}{l}\text { Organic } \\
\text { Chemistry }\end{array}$ & 2 & 47 & $\begin{array}{l}\text { Pharma-ceutical } \\
\text { Science }\end{array}$ & 1 & 17 & $\begin{array}{l}\text { Pathology and } \\
\text { Forensic Medicine }\end{array}$ & 2 & 47 & $\begin{array}{l}\text { Pulmo-nary and } \\
\text { Res-piratory } \\
\text { Medicine }\end{array}$ & 1 \\
\hline 18 & Bio-technology & 1 & 48 & Para-sitology & 1 & 18 & $\begin{array}{l}\text { Anesthe-siology } \\
\text { and Pain Medicine }\end{array}$ & 2 & 48 & $\begin{array}{l}\text { Infectious } \\
\text { Diseases }\end{array}$ & 1 \\
\hline 19 & $\begin{array}{l}\text { Agricultura-l } \\
\text { and Bio-logical } \\
\text { Sciences (miscel- } \\
\text { laneous) }\end{array}$ & 1 & 49 & Electro-chemistry & 1 & 19 & Drug Discovery & 2 & 49 & $\begin{array}{l}\text { Anesthe-siology } \\
\text { and Pain } \\
\text { Medicine }\end{array}$ & 1 \\
\hline 20 & Ophthalmo-logy & 1 & 50 & Cancer Research & 1 & 20 & Cell Biology & 2 & 50 & Physio-logy & 1 \\
\hline 21 & Neurology & 1 & 51 & $\begin{array}{l}\text { Polymers and } \\
\text { Plastics }\end{array}$ & 1 & 21 & $\begin{array}{l}\text { Ecology, Evolution, } \\
\text { Behavior and Sys- } \\
\text { tematics }\end{array}$ & 2 & 51 & Parasito-logy & 1 \\
\hline 22 & $\begin{array}{l}\text { Micro-biology } \\
\text { (medical) }\end{array}$ & 1 & 52 & $\begin{array}{l}\text { Molecular } \\
\text { Biology }\end{array}$ & 1 & 22 & $\begin{array}{l}\text { Astro-nomy and } \\
\text { Astro-physics }\end{array}$ & 1 & 52 & $\begin{array}{l}\text { Neurology } \\
\text { (clinical) }\end{array}$ & 1 \\
\hline 23 & $\begin{array}{l}\text { Pharma-cology, } \\
\text { Toxicology and } \\
\text { Phar-maceutics } \\
\text { (miscel-laneous) }\end{array}$ & 1 & 53 & $\begin{array}{l}\text { Physio-logy } \\
\text { (medical) }\end{array}$ & 1 & 23 & $\begin{array}{l}\text { Health, Toxico-logy } \\
\text { and Muta-genesis }\end{array}$ & 1 & 53 & $\begin{array}{l}\text { Strategy and } \\
\text { Manage-ment }\end{array}$ & 1 \\
\hline 24 & Food Science & 1 & 54 & $\begin{array}{l}\text { Speech and } \\
\text { Hearing }\end{array}$ & 1 & 24 & $\begin{array}{l}\text { Otorhino-laryngo- } \\
\text { logy }\end{array}$ & 1 & 54 & $\begin{array}{l}\text { Statistics, } \\
\text { Probabi-lity and } \\
\text { Uncer-tainty }\end{array}$ & 1 \\
\hline 25 & $\begin{array}{l}\text { Earth and } \\
\text { Planetary Sciences } \\
\text { (miscel-laneous) }\end{array}$ & 1 & 55 & Toxi-cology & 1 & 25 & $\begin{array}{l}\text { Artificial Intelli- } \\
\text { gence }\end{array}$ & 1 & 55 & Oncology & 1 \\
\hline
\end{tabular}




\begin{tabular}{|c|c|c|c|c|c|c|c|c|c|c|c|}
\hline 26 & $\begin{array}{l}\text { Otorhi-nolaryn- } \\
\text { gology }\end{array}$ & 1 & 56 & $\begin{array}{l}\text { Sociology and } \\
\text { Political Science }\end{array}$ & 1 & 26 & $\begin{array}{l}\text { Agricul-tural and } \\
\text { Biological Sciences } \\
\text { (miscel-laneous) }\end{array}$ & 1 & 56 & $\begin{array}{l}\text { Speech and } \\
\text { Hearing }\end{array}$ & 1 \\
\hline 27 & $\begin{array}{l}\text { Environ-mental } \\
\text { Engineering }\end{array}$ & 1 & 57 & $\begin{array}{l}\text { Pharma-cology } \\
\text { (medical) }\end{array}$ & 1 & 27 & $\begin{array}{l}\text { Dentistry (miscel- } \\
\text { laneous) }\end{array}$ & 1 & 57 & $\begin{array}{l}\text { Manage-ment, } \\
\text { Monitor-ing, } \\
\text { Policy and Law }\end{array}$ & 1 \\
\hline 28 & Geology & 1 & 58 & $\begin{array}{l}\text { Environ-mental } \\
\text { Science (miscel- } \\
\text { laneous) }\end{array}$ & 1 & 28 & $\begin{array}{l}\text { Cardio-logy and } \\
\text { Cardio-vascular } \\
\text { Medicine }\end{array}$ & 1 & 58 & $\begin{array}{l}\text { Radio-logy, } \\
\text { Nuclear } \\
\text { Medicine and } \\
\text { Imaging }\end{array}$ & 1 \\
\hline 29 & Dermato-logy & 1 & 59 & $\begin{array}{l}\text { Materials Science } \\
\text { (miscel-laneous) }\end{array}$ & 1 & 29 & $\begin{array}{l}\text { Micro-biology } \\
\text { (medical) }\end{array}$ & 1 & 59 & $\begin{array}{l}\text { Pharma-ceutical } \\
\text { Science }\end{array}$ & 1 \\
\hline 30 & $\begin{array}{l}\text { Gastro- } \\
\text { enterology }\end{array}$ & 1 & & & & 30 & $\begin{array}{l}\text { Pharma-cology, } \\
\text { Toxico-logy and } \\
\text { Pharma-ceutics } \\
\text { (miscel-laneous) }\end{array}$ & 1 & 60 & $\begin{array}{l}\text { Nature and } \\
\text { Landscape } \\
\text { Conser-vation }\end{array}$ & 1 \\
\hline & & & & & & & & & 61 & Bio-engineer-ing & 1 \\
\hline
\end{tabular}

